\title{
English Class Conversation sebagai Upaya Peningkatan Pendidikan dan Kesadaran Berbahasa \\ Inggris pada Anak-Anak Kampung Karangan Kota Surabaya
}

\author{
English Class Conversation as an Effort to Improve Language Education and \\ Awareness English to the Children of Kampung Karangan, the City of Surabaya
}

\author{
Nabila Izatul Muslimah', Rifka Fitriana Rahmadani ${ }^{1}$, Dwi Lestari ${ }^{1}$, Rama Eka \\ Ferdiansyah $^{1}$, Ranggamas Trisna Aditya ${ }^{2}$, Lia Juneitasari ${ }^{2}$, Muhammad Daffa \\ Aditya $^{2}$, Radhita Aisyah Resti Nariswari ${ }^{3}$, Rize Budi Amalia 4 \\ ${ }^{1}$ Departemen Ekonomi Islam, Fakultas Ekonomi dan Bisnis, Universitas Airlangga \\ ${ }^{2}$ Departemen Ilmu Ekonomi, Fakultas Ekonomi dan Bisnis, Universitas Airlangga \\ ${ }^{3}$ Departemen Kesehatan Masyarakat, Fakultas Kesehatan Masyarakat, Universitas \\ Airlangga \\ ${ }^{4}$ Departemen Kebidanan, Fakultas Kedokteran, Universitas Airlangga \\ *email: rizebudi.amalia@fk.unair.ac.id
}

\begin{abstract}
The WHO's declaration of COVID-19 as a pandemic has so many effects on global sectors and systems such as the health system, the agricultural sector, manufacturing, and the socioeconomic system. The government faces major challenges in dealing with the virus and adopting new policies to achieve maximum results under intense pressure during a pandemic. One of the sectors affected by the COVID-19 pandemic is the education sector. The impact of COVID-19 on the global education system affects all areas of teaching, research and services. Like-wise with Indonesia which has implemented the PSBB so that it houses all its students and replaces learning from offline to online. Elementary and junior high school students in Karangan, Surabaya have a problem, namely the lack of awareness of students regarding the importance of learning English so that the English Class Conversation (ECC) program was initiated face-to-face but still following the COVID-19 protocol system. Community service activities held using interactive learning methods in the form of $30 \%$ of the presenters and $70 \%$ of the participants. This activity was carried out for 3 weeks with 29 participants which belonged to a small group. The results obtained were that the participants had high motivation in taking part in learning English as evidenced by field data, namely 16 participants who got a B grade, meaning that the participants had high self-confidence when speaking English and could participate in learning well so that it meant that the ECC program was successful held in Karangan.
\end{abstract}

Keywords: Education, English Language, Offline learning,

10.20473/jlm.v5i1.2021.167-176

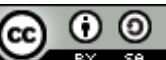

Open acces under CC BY-SA license

Creative Commons Attribution-ShareAlike 4.0 International License 


\begin{abstract}
Abstrak
Deklarasi WHO terhadap COVID-19 sebagai pandemi memiliki begitu banyak efek kepada sektor dan sistem global seperti sistem kesehatan, sektor agrikultur, manufaktur, dan sistem socio-economic. Pemerintah menghadapi tantangan besar dalam menangani virus serta mengadopsi kebijakan baru untuk mencapai hasil yang maksimal dibawah tekanan kuat di masa pandemi. Salah satu sektor yang berimbas akibat pandemi COVID-19 adalah sektor pendidikan. Dampak COVID-19 pada sistem pendidikan global mempengaruhi semua bidang pengajaran, penelitian, dan layanan. Begitu juga dengan Indonesia yang telah menerapkan PSBB sehingga merumahkan seluruh siswanya dan mengganti pembelajaran dari luring ke daring. Pelajar SD dan SMP di Kampung Karangan, Surabaya memiliki permasalahan yaitu kurangnya kesadaran pelajar terkait pentingnya mempelajari bahasa inggris sehingga tercetus program English Class Conversation (ECC) yang dilaksanakan dengan tatap muka namun tetap mengikuti sistem protokol COVID-19. Kegiatan pengabdian masyarakat yang diadakan menggunakan metode pembelajaran yang interaktif berupa $30 \%$ dari pemateri dan $70 \%$ dari partisipan. Kegiatan ini dilaksanakan selama 3 minggu dengan 29 partisipan dimana tergolong pada kelompok kecil. Hasil yang didapatkan yaitu peserta memiliki motivasi tinggi dalam mengikuti pembelajaran bahasa inggris dibuktikan dengan data lapangan yaitu 16 peserta yang mendapatkan nilai $\mathrm{B}$ dengan arti peserta memiliki kepercayaan diri yang tinggi saat berbicara bahasa inggris serta dapat mengikuti pembelajaran dengan baik

sehingga dapat diartikan bahwa program ECC telah berhasil dilaksanakan pada Kampung Karangan.
\end{abstract}

Kata Kunci: Bahasa inggris, pembelajaran luring, pendidikan

\title{
PENDAHULUAN
}

Pada 30 Januari 2020, World Health Organization (WHO) mendeklarasikan COVID-19 sebagai pandemi. Wabah ini memiliki begitu banyak efek kepada sektor dan sistem global seperti sistem kesehatan, sektor agrikultur, manufaktur, dan sistem socioeconomic. COVID-19 secara drastis telah mengganggu kehidupan pribadi miliaran orang secara global dan memaksa pemerintah di seluruh dunia untuk dengan cepat beradaptasi dengan realitas baru yang ditandai dengan peningkatan angka kematian, penguncian jarak sosial, serta teleworking (Oldekop, dkk., 2020). Gelombang pertama dari pandemik membanjiri sistem kesehatan masyarakat di seluruh dunia, menimbulkan ancaman tidak hanya bagi mereka yang terinfeksi dan menderita secara langsung, namun juga masyarakat luas (Weible, dkk., 2020). Pemerintah menghadapi tantangan yang sangat besar dalam menangani virus, mengadopsi kebijakan baru, mendukung komunitas, dan individu yang rentan, serta menemukan cara baru untuk mencapai hasil yang maksimal di bawah tekanan kuat di masa pandemi COVID-19 (Barbier \& Burgess, 2020; Naidoo \& Fisher, 2020).

Public Health England (2020) mengidentifikasi bahwa mengisolasi diri, melindungi, dan menjaga jarak sosial berdampak pada ketidakproposionalnya pada populasi yang rentan seperti orang tua, orang dengan ketidakmampuan belajar atau autisme, mereka yang memiliki kesehatan yang buruk serta komunitas minoritas. Krisis saat ini yang diakibatkan oleh COVID-19 telah mempengaruhi pengenalan teknologi digital di semua bidang aktivitas manusia, lebih dari sebelumnya (Shkalenko \& Fadeva, 2020). Tindakan pemutus rantai COVID-19 mewajibkan atau dapat dibilang memaksa instansi untuk mempekerjakan karyawan mereka di rumah, dan dengan 
demikian sejumlah besar orang yang bekerja di rumah telah mengintegrasikan teknologi yang ada dalam rutinitas kerja sehari-hari mereka (Béland dkk., 2020), begitu juga dengan sekolah atau universitas yang mengganti pembelajarannya dengan sistem daring. Dampak COVID-19 pada sistem pendidikan global sangat besar dan mempengaruhi semua bidang pengajaran, penelitian, dan layanan. DeVaney dkk. (2020) menyatakan bahwa lebih dari 1,6 miliar siswa terpengaruh di mana angka tersebut mewakili $91 \%$ siswa di dunia termasuk Indonesia.

Kasus COVID-19 yang kian meningkat membuat pemerintah Indonesia menerapkan Pembatasan Sosial Berskala Besar (PSBB), salah satunya di Kota Surabaya. Penerapan PSBB di Surabaya mempengaruhi banyak sektor, tidak terkecuali sektor pendidikan. Pemerintah Kota Surabaya merumahkan para siswa sebagai upaya pemutusan rantai COVID-19. Tindakan tersebut memaksa para pengajar untuk memodifikasi pembelajaran yang awalnya luring menjadi daring. Efek perubahan pembelajaran menjadi daring juga berimbas pada pelajar di Kampung Karangan.

Program pengabdian masyarakat yang dijalankan terletak di Jalan Karangan RT 02 RW 01, Kelurahan Sawunggaling, Kecamatan Wonokromo, Surabaya. Permasalahan utama yang dihadapi oleh pelajar SD dan SMP Kampung Sawunggaling yaitu kurangnya kesadaran pelajar terkait pentingnya mempelajari bahasa inggris. Asumsi pelajar Kampung Sawunggaling terhadap bahasa inggris adalah merupakan mata pelajaran yang tidak akan digunakan di masa depan. Untuk menanggulangi permasalahan tersebut, English Class Conversation dianggap dapat menjadi jawaban dari permasalahan pelajar yang telah dilaksanakan selama kurang lebihnya 3 minggu.

Bahasa Inggris dikenal sebagai bahasa asing pertama di Indonesia sejak tahun 1955 (Rintaningrum,

2015). Sebuah bahasa bisa disebut sebagai bahasa asing karena bahasa ini tidak digunakan secara luas di negara itu sendiri. Para pembicara atau warga negara tidak memiliki peluang banyak untuk menggunakan bahasa tersebut karena tidak ada bahasa ini dalam lingkup negaranya. Disebut sebagai bahasa asing pula dikarenakan bahasa itu tidak digunakan sebagai bahasa pengantar dalam pendidikan, bisnis, pemerintahan, pengadilan, atau bahasa di radio untuk penyiaran. Di Indonesia, bahasa Inggris diajarkan sebagai bahasa asing (EFL). Dalam suasana EFL, orang belajar bahasa Inggris agar dapat memanfaatkannya dalam berkomunikasi dengan penutur bahasa Inggris lainnya di seluruh dunia (Harmer, 2007). Dalam pengaturan ini juga, eksposur bahasa target di luar kelas tidak cukup. Para peserta didik juga jarang dapat mempraktikkan bahasa yang mereka pelajari dalam kehidupan sehari-hari (Brown, 2007). Kondisi ini tentunya berdampak pada penguasaan bahasa mereka.

Program ECC dibantu oleh Yayasan Al-Ichlas untuk mengumpulkan pelajar SD dan SMP serta sebagai penyedia tempat pembelajaran. ECC dilaksanakan dengan tatap muka dengan para peserta dengan syarat tetap menaati protokol kesehatan COVID-19 seperti menjaga jarak, menggunakan masker medis, dan hand-sanitizer. Ide pokok dari program ECC dilaksanakan dengan tatap muka yaitu: (1) Ada bukti yang menunjukkan bahwa pelajar selama karantina pandemi COVID-19 cenderung menghabiskan sedikit waktu untuk belajar dibandingkan saat sekolah tatap muka; (2) Semasa karantina COVID-19, pelajar mungkin merasa tertekan dan cemas sehingga berdampak negatif 
pada kemampuan mereka untuk berkonsentrasi pada tugas sekolah; dan (3) Penutupan sekolah dan kurangnya kontak langsung dapat membuat siswa kurang termotivasi secara eksternal untuk terlibat dalam kegiatan pembelajaran.

Tiga hal yang telah disebutkan merupakan kondisi nyata yang sedang dialami oleh pelajar SD dan SMP Kampung Karangan, dimana mereka merasa bosan dan kehilangan motivasi belajar khususnya bahasa inggris karena sekolah daring. Berdasarkan permasalahan tersebut maka peneliti mendesain pembelajaran dimana $30 \%$ berasal dari pemateri dan $70 \%$ berasal dari partisipan. Sistem pembelajaran yang akan digunakan yaitu pembelajaran yang menyenangkan, interaktif, dan dapat memotivasi peserta didik, serta meningkatkan efisiensi juga efektivitas terhadap kompetensi yang dicapai (Kemendikbud, 2016). Tujuan dari program ini adalah untuk meningkatkan kesadaran pelajar SD dan SMP di Kampung Karangan akan pentingnya belajar bahasa inggris serta meningkatkan motivasi belajar akibat turunnya daya juang akibat karantina selama COVID-19. Diharapkan seluruh peserta dapat tetap belajar bahasa inggris demi masa depan mereka setelah program ini selesai.

\section{METODE PENGABDIAN MASYARAKAT}

Kegiatan pengabdian masyarakat yang diadakan berupa pembelajaran bahasa Inggris yang berfokus pada percakapan dalam berbahasa Inggris kepada anak-anak yang berada di Yayasan Al-Ichlas, kampung Karangan, Kota Surabaya. Kegiatan ini merupakan salah satu bentuk pengabdian masyarakat yang dilakukan oleh mahasiswa Fakultas Ekonomi dan Bisnis dan Fakultas Kesehatan Masyarakat untuk memenuhi kegiatan Kuliah Kerja Nyata pada masa pandemi COVID-19. Pelaksanaan English Class Conversation (ECC) ini dilakukan dengan tetap memperhatikan protokol kesehatan seperti menggunakan hand-sanitizer, masker medis, dan menjaga jarak.

Metode yang digunakan adalah dengan memberikan pengajaran langsung kepada anak-anak berupa pronunciation (pengucapan) dalam bahasa inggris yang baik dan benar. Model kelas yang dikemas berupa 30\% dari pemateri dan $70 \%$ dari partisipan. Dalam hal ini diharapkan agar partisipan bisa memiliki peluang lebih untuk mempraktikkan kemampuan bahasa inggris yang dimiliki. Metode lain yang diberikan di kelas ini berupa permainan dan juga hiburan namun tetap dalam konteks bahasa inggris untuk menghindari kebosanan dari partisipan. Fokus dari kegiatan ini adalah untuk meningkatkan kesadaran anak-anak terhadap pentingnya berbahasa Inggris. Kegiatan ini diikuti oleh 29 anak yang dipisah menjadi 2 kelompok di hari yang berbeda untuk tetap menjaga protokol kesehatan agar tidak menimbulkan kerumunan.

Materi yang diajarkan kepada anak-anak yaitu : (1) Introducing Yourself; (2) Greetings; (3) Days and Months; (4) My Dream; dan (5) Pronounciation With Song. Kegiatan ECC dilaksanakan selama 3 minggu setiap hari senin, selasa, dan rabu. Pada minggu pertama ECC, materi yang disampaikan adalah Introducing Yourself dengan pemateri yang bernama Nabila Izatul Muslimah, Muhammad Daffa Aditya, Rifka Fitriana Rahmadani, dan Dwi Lestari. Lalu materi selanjutnya adalah Greetings dengan pemateri Ranggamas Trisna Aditya. Pada minggu kedua ECC, materi yang disampaikan adalah Days and Months dengan pemateri Nabila Izatul Muslimah dan Muhammad Daffa Aditya. Lalu materi selanjutnya adalah My Dreams dengan pemateri 
Lia Juneitasari dan Radhita Aisyah Resti Nariswari. Pada minggu ketiga ECC, materi yang disampaikan adalah Pronounciation With Song dengan pemateri Nabila Izatul Muslimah dan Ranggamas Trisna Aditya. Pelaksaan ECC ini dilaksanakan dengan partisipan 12-14 anak pada setiap pertemuan.

Alat yang digunakan selama kegiatan belajar mengajar adalah papan tulis sebagai alat untuk menjelaskan kepada peserta kemudian lembaran-lembaran materi yang dikemas dengan semudah mungkin agar dapat dimengerti oleh peserta. Pada minggu ketiga, pengajar menggunakan media lagu untuk melatih pendengaran dan juga pelafalan peserta dalam berbahasa inggris.

\section{HASIL DAN PEMBAHASAN}

English Class Conversation atau yang disingkat dengan ECC mendapatkan respons yang baik dari pelajar SD dan SMP pada Kampung Karangan yang dibantu oleh Yayasan Al-Ikhlas sebagai penyedia pelajar dan tempat. Respons yang baik ini terlihat dari banyaknya peserta yang hadir dalam program ECC yaitu sebanyak 29 peserta dari 30 pelajar yang telah didaftar oleh Yayasan Al-Ikhlas. Agar pembelajaran tetap sesuai dengan protokol dan meminimalisir risiko, maka dari 28 peserta dibagi menjadi dua sesi yang masing-masing terdiri dari 14 dan 15 peserta. Program ECC dilaksanakan tiga kali dalam seminggu yaitu setiap hari Senin, Selasa, dan Rabu pukul 13.00 di Yayasan Al-Ikhlas. Sebelum pembelajaran berlangsung, maka peserta diwajibkan untuk menerapkan physical distancing, pengecekkan masker, serta menggunakan handsanitizer yang sudah dipersiapkan sebelumnya. Selagi melakukan pengecekkan, maka meja ditata berjarak kemudian peserta baru diperbolehkan masuk.

Sasaran program ECC yaitu pelajar SD dan SMP di Kampung Karangan yang kurang percaya diri dengan kemampuannya dalam berbahasa inggris. Lokasi program ini dilaksanakan yaitu di Kampung Karangan, Kelurahan Sawunggaling, Kecamatan Wonokromo, Kota Surabaya RT 02. Yayasan Al-Ikhlas merupakan sebuah organisasi non-profit yang masih berada di Kawasan RT 02 dimana Yayasan ini merupakan wadah yang membantu para yatim-piatu serta fakir miskin baik secara finansial maupun nonfinansial.

Proses kegiatan belajar mengajar yang berlangsung kurang lebih satu bulan ini menggunakan lembar penilaian sebagai tolak ukur keaktifan peserta ECC. Segala bentuk keaktifan yang dilakukan oleh peserta akan diapresiasi dengan pemberian stiker pada lembar keaktifan dan juga hadiah bagi yang berani maju. Hal ini dilakukan untuk mengapresiasi usaha para peserta dalam mengikuti pembelajaran serta memotivasi mereka untuk tetap semangat dan tekun dalam belajar walaupun masih masa pandemi. Berdasarkan data lapangan selama satu bulan, maka yang didapatkan adalah sebagai berikut:

Tabel 1. Jumlah Peserta Menurut Jenjang Pendidikan Dan Jenis Kelamin

\begin{tabular}{|l|l|l|l|}
\hline No. & Jenjang Pendidikan & Pria & Wanita \\
\hline 1. & SD & 11 & 14 \\
\hline
\end{tabular}




\begin{tabular}{|c|c|c|}
\hline \begin{tabular}{|l|l}
2. & SMP \\
\end{tabular} & 2 & 2 \\
\hline Jumlah & 13 & 16 \\
\hline
\end{tabular}

Pada tabel di atas terdapat dua jenjang pendidikan yang mengikuti ECC pada Kampung Karangan yaitu SD dan SMP. Terdapat 11 peserta berjenis kelamin pria dan 14 peserta berjenis kelamin wanita pada jenjang SD. Kemudian terdapat 2 peserta pria dan 2 peserta wanita dengan jenjang pendidikan SMP. Apabila dilihat secara keseluruhan maka peserta wanita lebih banyak dibandingkan peserta pria dengan jenjang pendidikan yang didominasi oleh peserta SD.

\section{Tabel 2. Jumlah Kehadiran Peserta}

\begin{tabular}{|l|l|l|l|}
\hline \multirow{2}{*}{ No. } & Hari, Tanggal & Kehadiran & \multicolumn{2}{|l|}{} \\
\cline { 3 - 4 } & SD & SMP \\
\hline 1. & Rabu, 20 Januari 2021 & 12 & 2 \\
\hline 2. & Senin, 25 Januari 2021 & 13 & 2 \\
\hline 3. & Selasa, 26 Januari 2021 & 12 & 2 \\
\hline 4. & Rabu, 27 Januari 2021 & 13 & 2 \\
\hline 5. & Senin, 1 Februari 2021 & 12 & 2 \\
\hline 6. & Selasa, 2 Februari 2021 & 13 & 2 \\
\hline 7. & Rabu, 3 Februari 2021 & 12 & 2 \\
\hline
\end{tabular}

Sebelum pelaksanaan program ECC, telah dilakukan pembagian sesi yang terdiri dari dua sesi. Sesi pertama dan kedua dilaksanakan secara bergantian. Sesi pertama dimulai pada 20 Januari 2021 dan sesi kedua dimulai 25 Januari 2021. Pembagian sesi pada program ECC ditujukan agar selama kegiatan belajar mengajar tetap sesuai dengan protokol kesehatan COVID-19. Berdasarkan data di atas, dalam 3 minggu terdapat 7 pertemuan yang jumlah pesertanya selalu konstan mulai dari awal hingga akhir. Sehingga dapat ditarik kesimpulan bahwa pelajar SD dan SMP Kampung Karangan memiliki motivasi tinggi dalam mengikuti pembelajaran Bahasa Inggris.

*) $A=$ Sangat bagus

**) $B=$ Bagus

***) $C=$ Kurang

Terdapat empat indikator penilaian pada program ECC, yaitu: (1) Percaya diri; (2) Sopan santun; (3) Pelafalan bahasa inggris; (4) Kosakata bahasa inggris; dan (5) Aktif. Berdasarkan tabel di atas terdapat 3 nilai yang dimunculkan yaitu A menunjukkan sangat bagus, B menunjukkan bagus, dan C menunjukkan kurang. Terdapat 6 peserta yang mendapatkan nilai $\mathrm{C}$ yaitu terdapat kekurangan pada setiap indikator penilaian. Kemudian terdapat 16 peserta yang mendapatkan nilai B dimana peserta tersebut memiliki sopan santun dan percaya diri yang bagus namun masih perlu melatih pelafalan bahasa inggris dan memperbanyak kosakata. Lalu terdapat 7 orang peserta yang mendapatkan nilai A dimana peserta memiliki rasa percaya diri yang tinggi, sopan santun yang baik, pelafalan bahasa inggris yang bagus serta kaya akan kosakata bahasa inggris.

Dari data lapangan maka dapat ditarik kesimpulan bahwa peserta ECC sudah cukup bagus mengikuti pembelajaran bahasa inggris selama kurang lebih satu bulan namun masih perlu melatih pelafalan berbahasa inggris serta memperkaya kosakata. Hal ini terjadi akibat adanya perbedaan jenjang sekolah yang akhirnya membuat 
penyampaian materi tidak merata. Setidaknya ada 6 peserta yang dianggap kurang mampu mengikuti pembelajaran dengan baik karena kurang fokus serta harus mendapatkan perhatian lebih dari pengajar. Akan lebih baik apabila jenjang sekolah dapat lebih dikerucutkan agar materi yang disampaikan lebih merata dan peserta lebih fokus dengan pembelajaran. Hal ini dapat dilaksanakan apabila pandemi telah berakhir sehingga kegiatan ECC dapat terlaksana dengan maksimal.

\section{PENUTUP}

\section{Kesimpulan}

Bahasa Inggris adalah bahasa asing yang sangat penting untuk digunakan di zaman saat ini. Adanya pelatihan bahasa Inggris yang dimulai sejak dini dapat membantu membangun kepercayaan diri pelajar. Dalam membangun kepercayaan diri pelajar, metode pembelajaran yang digunakan oleh kelompok 194 KKN Universitas Airlangga adalah $30 \%$ dari pemateri dan $70 \%$ dari partisipan, serta diselingi dengan hiburan-hiburan untuk membangun suasana agar tidak terlalu monoton atau membosankan bagi pelajar. Kegiatan ini diikuti oleh

29 pelajar mulai dari jenjang SD hingga SMP kelas 8 secara tatap muka dengan menerapkan kesehatan. Lokasi KKN sendiri bertempat di Yayasan Al-Ichlas, Jalan Karangan, RT 02 RW 01, Kelurahan Sawunggaling, Kecamatan Wonokromo, Kota Surabaya, Provinsi Jawa Timur.

Materi yang disampaikan berjumlah lima materi, yakni Greetings, Introduction, Days and Months, Dreams and Occupations, Pronounciation with Songs. Penilaian dilakukan dengan mempertimbangkan lima indikator, yakni: (1) Percaya diri; (2) Sopan santun; (3) Pelafalan Bahasa Inggris; (4) Kosakata Bahasa Inggris; dan (5) Keaktifan. Berdasarkan indikator tersebut, didapatkan tiga predikat penilaian, dimana 7 orang mendapatkan predikat A, 16 orang mendapatkan predikat $\mathrm{B}$, dan 6 orang mendapatkan predikat C.

\section{Saran}

Program ini diharapkan dapat memberikan alternatif pengajaran kepada para tenaga pendidik khususnya pada tenaga pendidik di Yayasan Al-Ichlas. Penelitian ini memberikan wawasan baru bahwa kelas yang biasanya dilaksanakan dengan jumlah pelajar yang banyak, kurang efektif dibandingkan dengan kelas kelompok kecil dalam penyampaian materi. Pengemasan materi dan cara ajar yang bervariasi serta lebih menyenangkan bagi para pelajar cenderung memberi efek positif bagi penerimaan materi mereka. Pengerucutan jenjang-jenjang sekolah sangat penting bagi pemilihan materi, sehingga penelitian kedepannya dapat menggunakan pengerucutan jenjang sekolah agar materi yang diterima lebih sesuai dengan masing-masing pelajar. Diadakannya pretest dan post-test juga akan sangat membantu mengukur perkembangan pelajar dalam belajar bahasa Inggris, dan dapat mengukur seberapa efektif suatu metode pengajaran.

\section{LAMPIRAN}




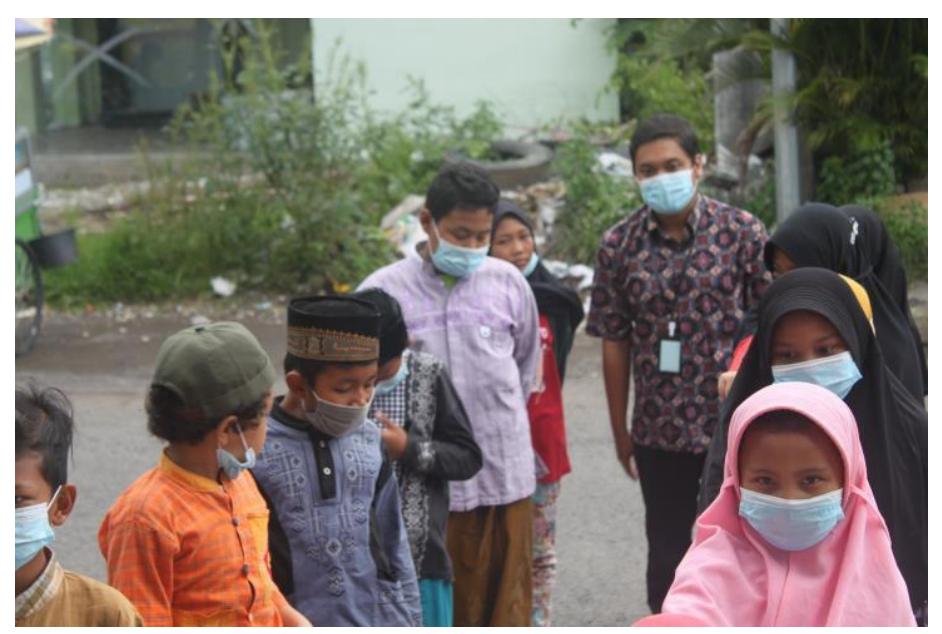

Gambar 1. Pengaturan jarak sebelum kegiatan

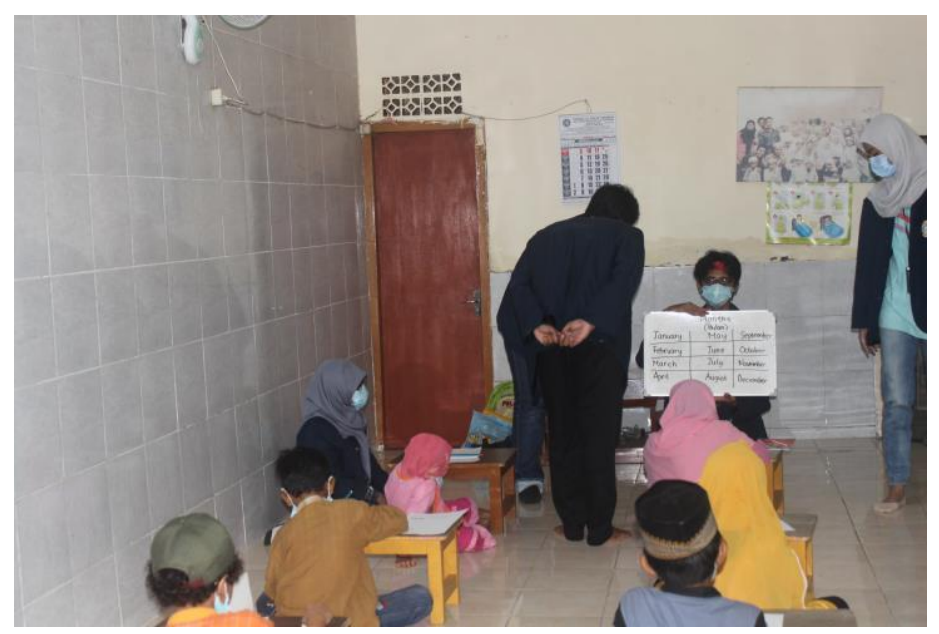

Gambar 2. Pembelajaran ECC

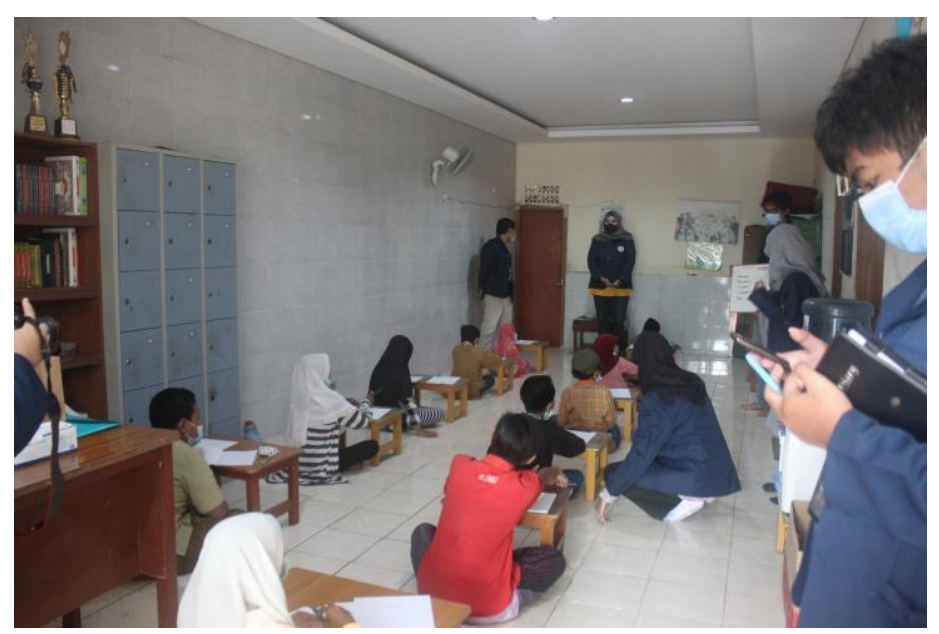

Gambar 3. Pembelajaran ECC 


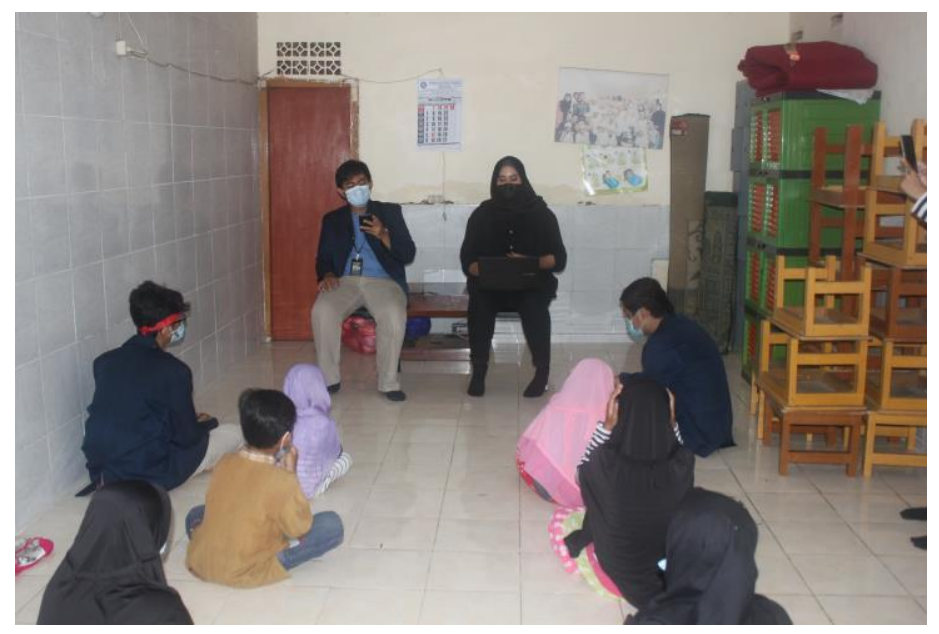

Gambar 4. Pronunciation with song

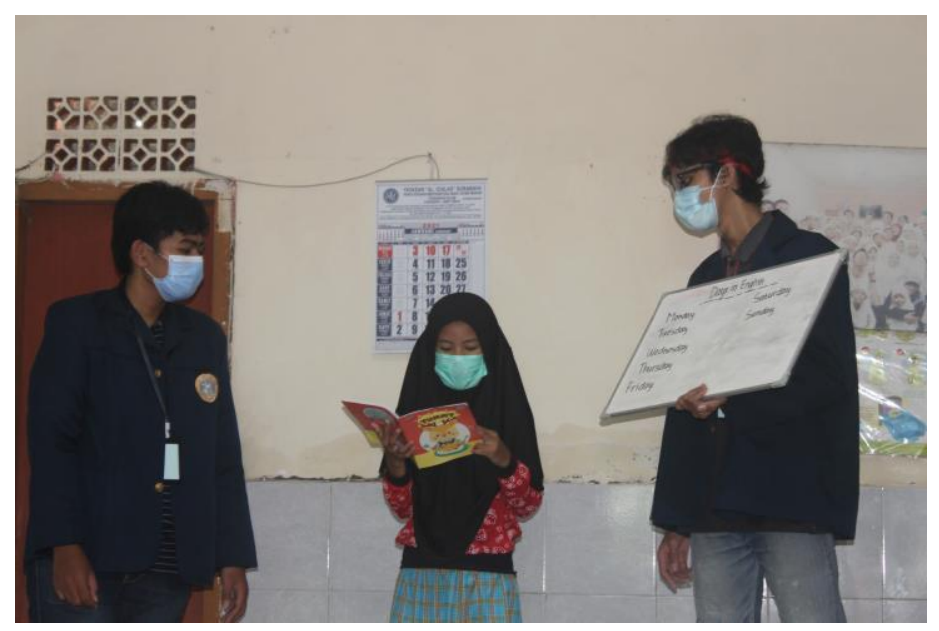

Gambar 5. Pembelajaran ECC 


\section{DAFTAR PUSTAKA}

Brown., H. D. (2007). Principles of Language Learning and Teaching (4th ed.) New York: Longman.

Harmer, J. (2007). The Practice of English Language Teaching (4thed.). Harlow, England: Longman.

Kurniasih, I., \& Sani, B. (2014). Implementasi Kurikulum 2013 Konsep dan Penerapan. Kementrian Pendidikan Dan Kebudayaan, 1-162.

Rahayu, Dwi Ide. 2020. The Acquisition and Learning of EFL in A Non-formal English Education in Indonesia. Journal of English Education, 5(2), 86-94 DOI: https://doi.org/10.31327/jee.v5i2.1312

Rintaningrum, R. (2015). Bahasa Inggris Tidak Perlu Dihapus dari Kurikulum 2013 Sekolah Dasar Pendahuluan: Pentingnya Memahami Konsep Ilmu Penghapusan Bahasa Inggris pada Kurikulum 2013 Sekolah Dasar.

Souriyavongsa, T., Rany, S., Jafre Zainol Abidin, M., \& Lai Mei, L. (2013). Factors Causes Students Low English Language Learning: A Case Study in the National University of Laos. International Journal of English Language Education, 1(1), 179-192. https://doi.org/10.5296/ijele.v1i1.3100

Syahwin, Nikelas. 1988. Pengantar Linguistik Untuk Guru Bahasa. Jakarta: DepDikbud Dikti 